\title{
The TRPC6-AMPK Pathway is Involved in Insulin-Dependent Cytoskeleton Reorganization and Glucose Uptake in Cultured Rat Podocytes
}

\author{
Patrycja Rachubik ${ }^{a}$ Maria Szrejder ${ }^{a}$ Dorota Rogacka ${ }^{a}$ Irena Audzeyenka

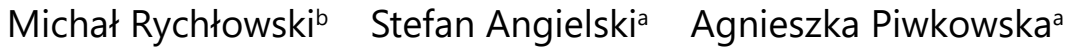 \\ aMossakowski Medical Research Centre Polish Academy of Sciences, Laboratory of Molecular and \\ Cellular Nephrology, Gdańsk, bUniversity of Gdańsk - Medical University of Gdańsk, Intercollegiate \\ Faculty of Biotechnology, Laboratory of Virus Molecular Biology, Gdańsk, Poland
}

\section{Key words}

AMP-activated protein kinase $\cdot$ Calcium $•$ Cytoskeleton $•$ Glucose uptake $\bullet$ Insulin $\bullet$ Rho family of GTPases

\begin{abstract}
Background/Aims: Podocytes are dynamic polarized cells on the surface of glomerular capillaries that are an essential part of the glomerular filtration barrier. AMP-activated protein kinase (AMPK), a key regulator of glucose and fatty acid metabolism, plays a major role in obesity and type 2 diabetes. Accumulating evidence suggests that TRPC 6 channels are crucial mediators of calcium transport in podocytes and are involved in regulating glomerular filtration. Here we investigated whether the AMPK-TRPC6 pathway is involved in insulin-dependent cytoskeleton reorganization and glucose uptake in cultured rat podocytes. Methods: Western blot and immunofluorescence analysis confirmed AMPK $\alpha$ and TRPC6 expression, the phosphorylation of proteins associated with actin cytoskeleton reorganization (PAK, rac1, and cofilin), and the expression of insulin signaling proteins (Akt, Insulin receptor). Coimmunoprecipitation and immunofluorescence results demonstrated AMPK $\alpha /$ TRPC6 interaction. To ask whether TRPC6 is involved in the insulin regulation of glucose transport, we measured insulin-dependent $\left(1,2-{ }^{3} \mathrm{H}\right)$-deoxy-D-glucose uptake into podocytes after reducing TRPC6 activity pharmacologically and biochemically (TRPC6 siRNA). Results: The results suggested a key role for the TRPC6 channel in the mediation of insulin-dependent activation of AMPK 22 and glucose uptake. Moreover, AMPK and TRPC6 activation were required to stimulate the Rac1 signaling pathway. Conclusion: These results suggest a potentially important new mechanism that regulates glucose transport in podocytes and that could be injurious during diabetes.




\section{Cellular Physiology Cell Physiol Biochem 2018;51:393-410

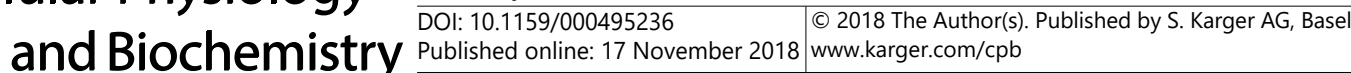 \\ Rachubik et al.: Insulin Regulates TRPC6-AMPK Pathway in Podocytes}

\section{Introduction}

The impairment of insulin signaling and insulin pathways in skeletal muscle, fat tissue, and the liver is central to the development of type 2 diabetes. The resulting dysregulation of glucose and fat metabolism leads to kidney failure and/or to cardiovascular complications. Indeed, the majority of patients with albuminuria and end-stage renal failure in Western countries show abnormalities in insulin production or in insulin effectiveness $[1,2]$.

Podocytes are uniquely sensitive to insulin and have similarities to skeletal muscle and fat cells with respect to insulin-stimulated glucose uptake kinetics and the expression of glucose transporters (GLUTs) [3, 4]. Recent studies have shown that insulin can dynamically remodel the actin cytoskeleton of podocytes and that this is critically important for maintaining the integrity of the glomerular filtration barrier. Actin reorganization leads to changes in podocyte structure, and insulin receptor stimulation causes the retraction of podocyte processes [5]. Some groups have suggested that insulin plays a role in the control of podocyte contractility, which may contribute to glomerular permeability [6-9]. We recently demonstrated that insulin remodels the actin cytoskeleton and increases the albumin permeability of both isolated rat glomeruli and podocytes; we further showed that the underlying mechanism is calcium-dependent $[10,11]$. Moreover, in mouse podocytes, insulin increases the steady-state cell surface expression of TRPC6 channels [9].

Overexpression or gain of function of the TRPC 6 channel can drive podocyte effacement, and TRPC6 overexpression in the mouse kidney induces proteinuria [12]. An increase in intracellular calcium downregulates the expression of nephrin and synaptopodin and stimulates RhoA activity, which in turn causes F-actin derangement and a decrease in foot processes [13]. Furthermore, TRPC6 gene mutations are linked to human proteinuric kidney disease, focal segmental glomerulosclerosis, and loss of podocytes [14].

We postulated that dynamic responses in podocytes and in their foot processes are mediated by cytoskeletal elements and by $\mathrm{Ca}^{2+}$-dependent processes. However, the means by which proteins regulate actin dynamics in podocyte foot processes are not fully understood, especially in diabetes. In many types of glomerular diseases, the integrity of the actin cytoskeleton is altered in podocytes, indicating that proper organization and regulation of the actin cytoskeleton are essential for podocyte structure and function [15].

AMP-activated protein kinase (AMPK) activity appears to positively regulate insulindependent glucose uptake and insulin signaling [16, 17]; however, AMPK activity is suppressed in disorders associated with insulin resistance $[4,18]$. The AMPK is composed of three subunits, one catalytic, termed $\alpha$, and two regulatory, termed $\beta$ and $\gamma$. The activation of AMPK requires the phosphorylation of threonine 172 (Thr172) within the catalytic $\alpha$ subunit by upstream kinases, namely the $\mathrm{Ca}^{2+} /$ calmodulin-dependent kinase kinase- $\beta$ (CaMKK- $\beta$ ) and/or the LKB1-STRAD-M025 complex [19]. Hypoxia and contractile activity also activate AMPK. In addition to the potential requirement for AMPK activity, normal regulation of contraction- and exercise-stimulated glucose uptake also requires the Rho GTPase Rac1 [20, 21], which is activated by insulin and which induces actin cytoskeleton remodeling at the plasma membrane in skeletal muscle cells [22]. Rac1 mediates this process by inducing cortical F-actin remodeling, which involves the recruitment of actin regulatory proteins such as cofilin and Arp2/3 to the actin filaments [23]. In addition, Rac1 signals p21-activated kinase 1 (PAK1) in skeletal muscle and facilitates PAK1 phosphorylation in response to insulin [24]. Insulin-stimulated PAK1 activation is decreased in human skeletal muscle in both acute (intralipid infusion) and chronic (obesity and type 2 diabetes) insulin resistant states [22], suggesting that PAK1 is a required element for maintaining euglycemia and insulin sensitivity. These findings suggest that Rac1 and downstream signaling to the actin cytoskeleton constitute an important dysfunctional pathway in insulin-resistant states. This mechanism not be recognized in podocytes. 


\section{Cellular Physiology Cell Physiol Biochem 2018;51:393-410 \begin{tabular}{l|l|l} 
and Biochemistry Published online: 17 November 2018 & $\begin{array}{l}\odot 2018 \text { The Author(s). Published by S. Karger AG, Basel } \\
\text { www.karger.com/cpb }\end{array}$ \\
\hline
\end{tabular}

In the present study, we investigated whether the TRPC6-AMPK pathway is involved in insulin-mediated cytoskeleton reorganization and glucose uptake. Our results identified a potentially important new mechanism that may be injurious to podocytes in diabetes and consequently interfere with the intracellular transport of glucose.

\section{Materials and Methods}

\section{Preparation and culture of rat podocytes}

All experimental procedures were performed in accordance with directive 2010/63/EU and were approved by the Local Bioethics Commission at the Medical University of Gdansk.

We used female Wistar rats weighting 100-120 g. Podocytes were isolated as described previously [25]. Experiments were conducted using podocytes cultivated for 12-20 days. Cell phenotypes were established using podocyte-specific antibodies against Wilms tumor-1 protein (WT-1; Biotrend Koeln, Germany) and synaptopodin (Progen, Heidelberg, Germany).

\section{Western blot analysis}

To obtain podocyte lysate, the cells were treated with lysis buffer (1\% Nonidet P-40, $20 \mathrm{mM}$ Tris, 140 $\mathrm{mM} \mathrm{NaCl}, 2 \mathrm{mM}$ EDTA, 10\% glycerol) in the presence of a protease inhibitor cocktail and homogenized at $4{ }^{\circ} \mathrm{C}$ by scraping. Proteins in the supernatant $(12 \mu \mathrm{g})$ were separated on a $10 \%$ SDS-polyacrylamide gel and electrotransferred to nitrocellulose membranes. The following primary antibodies were used for Western blotting: anti-p-AMPK $\alpha$ (Thr172) (1:1000, Cell Signaling Technology), anti-AMPK $\alpha$ (1:1000, Cell Signaling Technology), anti-p-insulin R $\beta$ (Tyr1150-1151) (1:200, Santa Cruz Biotechnology), anti-insulin R $\beta$ (1:200, Santa Cruz Biotechnology), anti-p-Akt1/2/3 (Ser473) (1:400, Santa Cruz Biotechnology), antiAkt1/2/3 (1:400, Santa Cruz Biotechnology), anti-TRPC6 (1:1000, Sigma-Aldrich), anti-p-PAK 1/2/3 (Thr 423/402/421) (1:800, Sigma-Aldrich), anti-p-PAK1/2/3 (Ser144/141/139), anti-PAK1/2/3 (1:800, Cell Signaling Technology), anti-ROCK1 (1:1000, Cell Signaling Technology), anti-ROCK2 (1:1000, Cell Signaling Technology), anti-p-cofilin (1:1000, Sigma-Aldrich), anti-cofilin (1:1000, Santa Cruz Biotechnology), p-Rac1 (Ser71) (1:1000, OriGene), and anti-actin (1:3000, Sigma-Aldrich). To detect the primary antibodies, the membranes were incubated with the appropriate alkaline phosphatase-labeled secondary antibodies. The protein bands were visualized using the colorimetric 5-bromo-4-chloro-3-indolylphasphate/nitroblue tetrazolium (BCIP/NBT) system.

\section{Measurement of glucose uptake}

Glucose uptake was measured as described previously [4] by the addition of $1 \mu \mathrm{Ci} /$ well of $\left(1,2-{ }^{3} \mathrm{H}\right)$ deoxy-D-glucose diluted in non-radioactive glucose to a final concentration of $50 \mu \mathrm{M}$ with or without 300 $\mathrm{nM}$ insulin. After incubation for $3 \mathrm{~min}$, intracellular and extracellular radioactivity was measured by liquid scintillation counting using a MicroBeta2 Microplate Counter (Perkin Elmer, Waltham, MA, USA).

\section{RNA interference and cell transfection}

Podocytes were transfected with small interfering RNAs (siRNAs) that targeted TRPC6 (OriGene), AMPK $\alpha 1$, AMPK $\alpha 2$ (Santa Cruz Biotechnology) or with control, non-silencing siRNA (scrambled siRNA, negative control) (OriGene or Santa Cruz Biotechnology). Cells were cultured in RPMI 1640 supplemented with 10\% FBS. One day before the experiment, the culture medium was changed to antibiotic-free RPMI 1640 supplemented with $10 \%$ FBS. The cells were transfected with siRNAs using siRNA Transfection Reagent (Santa Cruz Biotechnology) according to the manufacturer's instructions. Briefly, the targeted siRNA or scrambled siRNA were diluted in Transfection Medium (final concentration, $80 \mathrm{nM}$ ), mixed with siRNA Transfection Reagent, and incubated for $30 \mathrm{~min}$ at room temperature. Then Transfection Medium was added to the transfection mixture, mixed gently, and added to the podocytes. After $7 \mathrm{~h}$, we added grow medium supplemented with $2 \times$ higher concentrations of FBS and antibiotics. The podocytes were incubated for an additional $24 \mathrm{~h}$. After transfection, gene silencing was checked at the protein level by Western blotting. 


\section{Cellular Physiology Cell Physiol Biochem 2018;51:393-410 \begin{tabular}{l|l|l} 
and Biochemistry Published online: 17/November 2018 & $\begin{array}{l}\text { (c) } 2018 \text { The Author(s). Published by S. Karger AG, Basel } \\
\text { www.karger.com/cpb }\end{array}$ \\
\hline
\end{tabular} \\ Rachubik et al.: Insulin Regulates TRPC6-AMPK Pathway in Podocytes}

\section{Immunofluorescence}

Podocytes were seeded on coverslips coated with type 1 collagen (Becton Dickinson Labware, Becton, UK) and cultured in RPMI 1640 supplemented with 10\% FBS. Cells were fixed in PBS plus 4\% formaldehyde for $10 \mathrm{~min}$ at room temperature. Fixed podocytes were permeabilized with $0.3 \%$ Triton-X for 3-4 min and then blocked with PBSB solution (PBS plus 2\% FBS, 2\% BSA, and 0.2\% fish gelatin) for $1 \mathrm{~h}$. After blocking, cells were incubated with anti-cofilin (1:50), anti-TRPC6 (1:100), anti-AMPK 1 (1:100), and anti-AMPK 2 (1:100) antibodies in PBSB at $4^{\circ} \mathrm{C}$ for $1 \mathrm{~h}$. The primary antibodies were incubated with blocking peptide to eliminate non-specific staining. Next, the cells were washed three times with cold PBS and incubated with secondary antibodies conjugated to Alexa Fluor 488 (1:1000) or Alexa Fluor 546 (1:1000). Actin was stained using Alexa Fluor 594 phalloidin (1:200). Specimens were imaged using a confocal laser scanning microscope (Leica SP8X) with a $63 \times$ oil immersion lens.

\section{Immunoprecipitation}

Cell extracts were pre-cleared with mouse IgG plus Protein A/G-PLUS Agarose at $4^{\circ} \mathrm{C}$ for $1 \mathrm{~h}$ and then incubated with a primary antibody plus Protein A/G-PLUS Agarose at $4^{\circ} \mathrm{C}$ overnight. The agarose beads were washed gently with lysis buffer. Proteins were eluted from the beads by adding SDS loading buffer. The mixture was then boiled for $5 \mathrm{~min}$ and subjected to Western blot analysis.

Rac1 activity assay

Rac1 activation was measurement in the supernatant using a commercially available G-LISA Rac1 Activation Assay Biochem Kit (BK128; Cytoskeleton, Inc.)

\section{Statistical analysis}

Statistical analyses were performed using one-way ANOVA followed by the Student-Newman-Keuls test to determine significance. Values are reported as means \pm SEMs. Significance was set at $P<0.05$.

\section{Results}

Intracellular calcium signaling regulates insulin signal transduction in cultured rat podocytes

First, we investigated the effects of intracellular calcium signaling on the phosphorylation of proteins involved in insulin signal transduction in cultured rat podocytes (Fig. 1). Insulin treatment ( $300 \mathrm{nM}, 5 \mathrm{~min}$ ) increased the phosphorylation of the insulin receptor (IR) by $262 \%$ (from $0.34 \pm 0.07$ to $1.23 \pm 0.24, \mathrm{n}=4, P<0.05$ ) and increased the phosphorylation of Akt by $32 \%$ (from $1.69 \pm 0.04$ to $2.24 \pm 0.03, n=4, P<0.05$ ). Incubation of the podocytes with inhibitors of calcium extrusion, namely $\mathrm{La}^{3+}(1 \mathrm{mM})$, caloxin2A1 (CX, $\left.0.3 \mathrm{mM}\right)$, or CB-DMB $(50 \mu \mathrm{M})$ had no effect on IR and Akt phosphorylation. Insulin treatment of podocytes in the presence of all of the inhibitors of calcium extrusion increased the phosphorylation of IR and Akt to similar extents.

Next, we evaluated the effect of a TRPC inhibitor (SKF96365, $100 \mu \mathrm{M}, 15 \mathrm{~min}$ preincubation) on insulin signal transduction in the cultured podocytes. SKF96365 did not affect IR phosphorylation, but it blocked the effect of insulin on Akt phosphorylation $(1.47 \pm 0.11$ vs. control $1.46 \pm 0.18$, n=4, Fig. 1$)$. We then evaluated the role of TRPC 6 on insulin signal transduction in podocytes by knocking down TRPC6 expression using siRNA (Fig. 2A). There was a significant decrease in TRRP6 protein expression in podocytes transfected with TRPC6 siRNA compared to podocytes transfected with the control scrambled siRNA (55\% decrease, $0.221 \pm 0.039$ vs. control $0.490 \pm 0.013, \mathrm{n}=4, P<0.05)$. Downregulation of TRPC6 expression abolished insulin-induced Akt phosphorylation without affecting IR phosphorylation (Fig. 2B, 2C). 
Intracellular calcium
signaling regulates

the insulin-dependent activation of AMPK kinase and glucose uptake in cultured rat podocytes

AMP-activated protein kinase (AMPK) is a major regulator of insulindependent glucose uptake and insulin signaling in podocytes [4]. We found that insulin (300 nM, $5 \mathrm{~min}$ ) induced the phosphorylation of the AMPKa subunit $(0.799 \pm 0.081$ vs. control $0.569 \pm 0.042, \mathrm{n}=4, P<0.05$, Fig. $3 \mathrm{~A})$. We hypothesized that insulin might increase AMPK $\alpha$ phosphorylation by activating TRPC channels. Indeed, preincubation of podocytes with the TRPC channel inhibitor SKF96365 (100 $\mu \mathrm{M}, 15$ min preincubation) abolished the effect of insulin on AMPK phosphorylation (Fig. 3A). The same effect was observed after downregulation of TRPC6 expression in podocytes (Fig. 3B). We then demonstrated that podocytes were insulinsensitive and that insulin stimulation increased glucose uptake by about $40 \%$ (Fig. 3C). To determine the effect of TRPC channels on insulin-dependent glucose uptake, we evaluated the effect of SKF96365 (Fig. 3C) or specific TRPC6 inhibitor SAR7334 $(1 \mu \mathrm{M}, 15 \mathrm{~min}$, Fig. 3D) and downregulation of TRPC6 expression (Fig. 3E) and found that all blocked insulin-dependent glucose uptake. We therefore postulated that TRPC6 channels play an essential role in the regulation of insulin-dependent signaling and thus in the regulation of glucose uptake in podocytes.
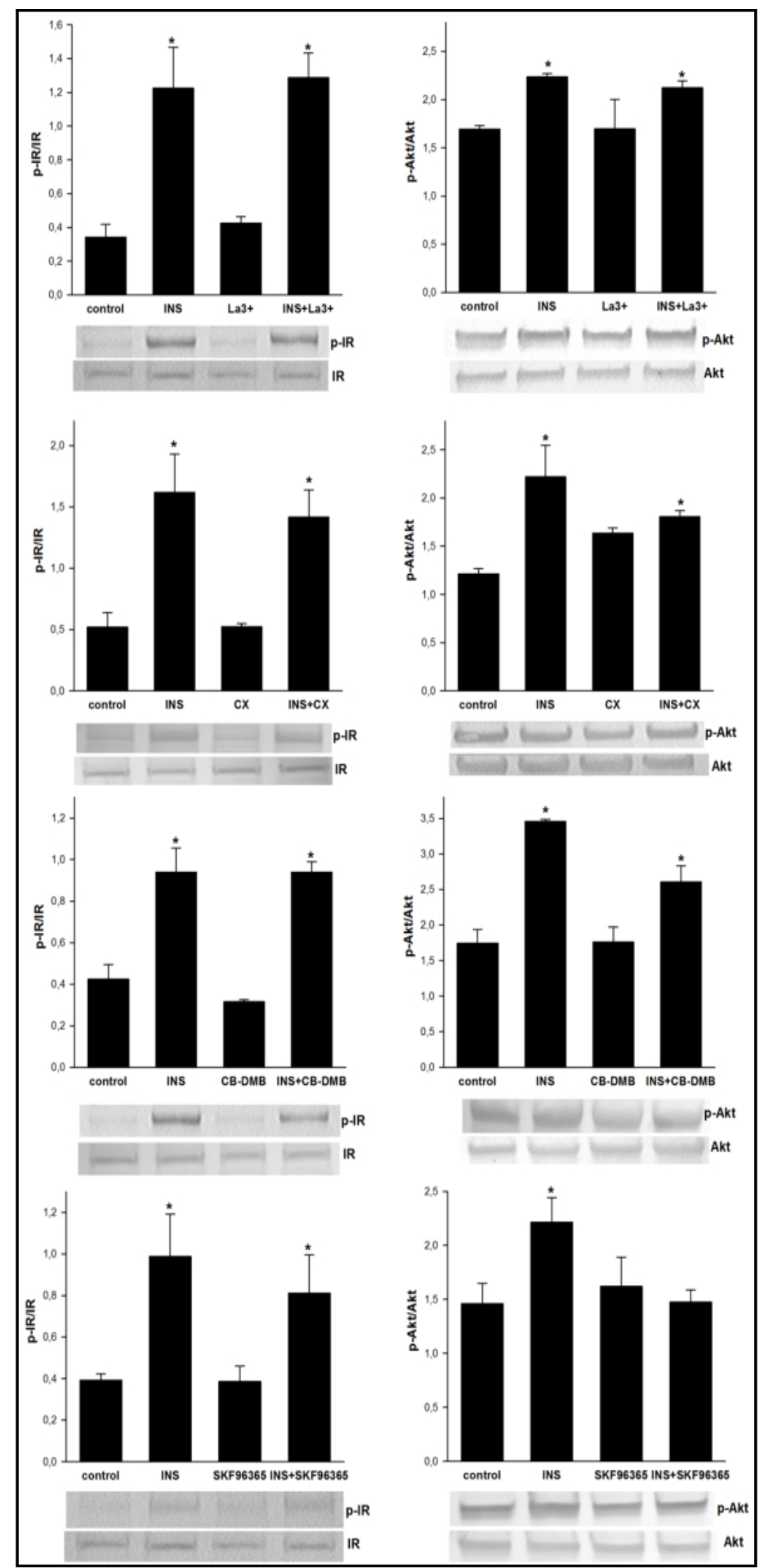

Fig. 1. The effect of intracellular calcium signaling on the phosphorylation of proteins involved in insulin signal transduction in cultured rat podocytes. Podocytes were incubated with or without insulin ( $300 \mathrm{nM}, 5 \mathrm{~min}$ ) and the indicated calcium signaling inhibitors. Cell lysates were analyzed by immunoblotting using anti-IR, anti-pIR (Tyr1150/1151), anti-Akt, and anti-p-Akt (Ser473) antibodies. Values are reported as the means \pm SEMs of four independent experiments. ${ }^{*} \mathrm{P}<0.05$ compared to control. 


\section{Cellular Physiology Cell Physiol Biochem 2018;51:393-410

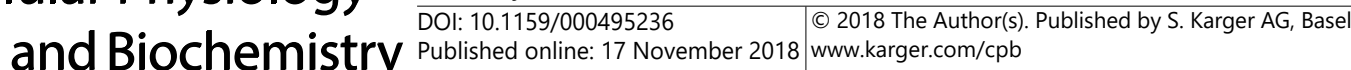

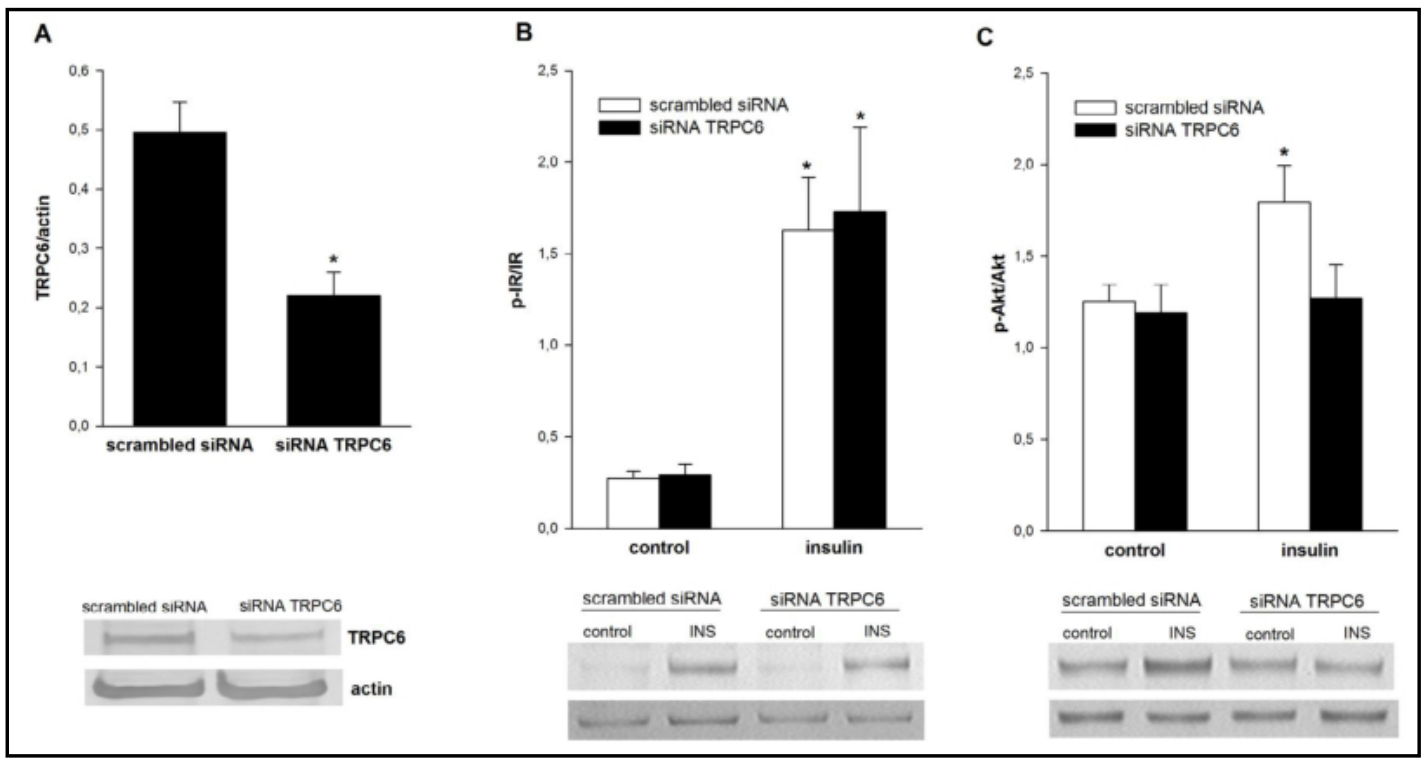

Fig. 2. The influence of TRPC6 channels on insulin signal transduction in cultured rat podocytes. (A) The effect of TRPC6 siRNA on TRPC6 expression. Densitometric measurements of the TRPC6 bands were normalized to the actin band. The influence of TRPC6 downregulation on insulin-dependent phosphorylation of insulin receptor (B) and kinase Akt (C). Values are reported as the means \pm SEMs of four to six independent experiments. ${ }^{*} \mathrm{P}<0.05$ compared to appropriate control.

The role of insulin in TRPC6 channel interactions with AMPKo subunits in cultured rat podocytes

Many groups have shown that TRPC6 is part of a larger signaling complex in the slit diaphragm and that this complex plays an important role in the regulation of podocyte function. We investigated whether AMPK $\alpha$ subunits associate with TRPC6 as well as the possible role of insulin in this interaction. After mixing podocyte extract with antibodies against AMPK $\alpha 1$ or AMPK $\alpha 2$ subunits, TRPC6 was detected in both immunoprecipitates. Similarly, antibodies to TRPC6 coimmunoprecipitated AMPK $\alpha 1$ and AMPK $\alpha 2$ (Fig. 4A). We also found that insulin increased the amount of TRPC6 that co-immunoprecipitated with AMPK $\alpha 2$ subunits by approximately $45 \%$ (from $0.579 \pm 0.064$ to $0.838 \pm 0.055, n=3, P<0.05$, Fig. 4B). The quantitative analysis confirmed that insulin increased the colocalization of TRPC6 with AMPK $\alpha 2$ subunits (from $57.5 \%$ to $72 \%, n=8, P<0.05$, Fig. 4D). Insulin did not increase the level of TRPC6 that colocalized with AMPK $\alpha 1$ subunits.

The role of TRPC6 and AMPK in insulin-dependent regulation of Rac1 activity in podocytes

The small GTPase Rac1 is a major regulator of actin remodeling, and cytoskeletal rearrangement is required for GLUT4 translocation in response to insulin [26]. Because we found that inhibition of TRPC6 decreased insulin-stimulated glucose uptake, we hypothesized that this might be due to impaired Rac1-dependent regulation of the actin cytoskeleton. Rac1 is activated when bound to GTP. We found that insulin induces activation of Rac1 by $36 \%$ compared to control $(1.34 \pm 0.02$ vs. control $0.86 \pm 0.02, n=4, P<0.05$ ). Moreover, preincubation of podocytes with TRPC inhibitor (SKF96365, $100 \mu \mathrm{M}, 15 \mathrm{~min}$ ) attenuated the effect of insulin on Rac1 activity (Fig. 5A). To determine the influence of AMPK on Rac1, we modified AMPK kinase activity using the AMPK activator metformin $(2 \mathrm{mM})$ and the AMPK inhibitor compound C $(100 \mu \mathrm{M})$ (Fig. 5B). We found that metformin increased glucose uptake by $37 \%(0.993 \pm 0.063$ vs. control $0.725 \pm 0.048, P<0.05$, Fig. 5 C $)$. However, the AMPK inhibitor compound $\mathrm{C}$ decreased glucose uptake to $0.617 \pm 0.029(P<0.05$, Fig. $5 \mathrm{C})$. 
Similar to insulin, metformin also increased Rac1 activity by $39 \%$ $(1.21 \pm 0.14$ vs. control $0.87 \pm 0.06, \quad \mathrm{n}=6, \quad P<0.05$, Fig. 5D) and Rac1 serine 71 phosphorylation by $25 \%(1.53 \pm 0.07$ vs. control $1.22 \pm 0.09, \quad \mathrm{n}=5, \quad P<0.05$, Fig. 5E). Inhibiting AMPK activity with compound C decreased Rac1-GTP binding by $29 \%$ and Rac1 phosphorylation by $20 \%$.

We then evaluated the roles of the AMPK $\alpha 1$ and AMPK 22 subunits in the regulation of Rac1 activity. We knocked down AMPK $\alpha 1$ and AMPK 22 expression using siRNA(Fig. 6A, B). Only downregulation of AMPK 22 expression decreased Rac1 phosphorylation in the control (by 21\%, $P<0.05$, Fig. 6D) and in the presence of metformin $(25 \%, P<0.05$, Fig. 6D). These data suggest that activation of both TRPC6 and AMPK $\alpha 2$ are necessary to activate Rac1 in cultured rat podocytes.

Insulin-mediated activation of downstream targets of Rho kinases is TRPC6dependent

We next evaluated the influence of TRPC6 on the insulin-dependent regulation of downstream targets of Rho kinases. I n s u lin - s t i m u lated activation of Rac1 activates the serine/threonine kinase PAK in skeletal muscle [22]. Activation of PAK involves phosphorylation of the Thr423 and Ser141 residues, dissociation of the dimer, and release of the catalytic domains [27]. In podocytes, insulin stimulation (300 $\mathrm{nM}, 5 \mathrm{~min}$ ) increased PAK Ser141 phosphorylation by $71 \%(1.20 \pm 0.24$ vs. control $0.70 \pm 0.03)$ and PAK Thr423 phosphorylation by $33 \%$ ( $1.54 \pm 0.11$ vs. control $1.16 \pm 0.09$ ), $P<0.05$ for both. Furthermore, we found that preincubating cells with SKF96365 $(100 \mu \mathrm{M})$ or downregulation of TRPC6 by siRNA attenuated the effect of insulin on PAK phosphorylation in podocytes (Fig. 7). We also

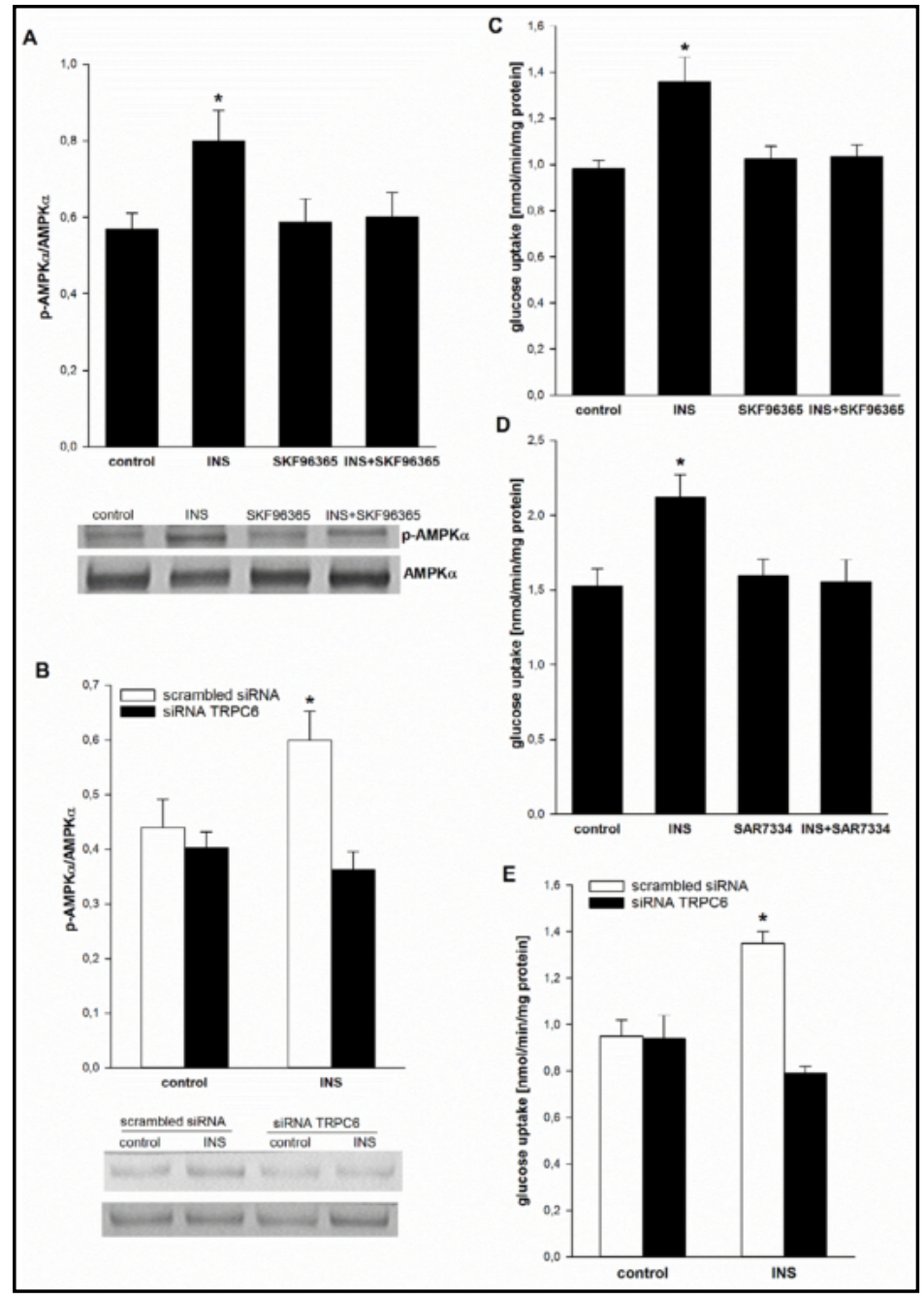

Fig. 3. TRPC6 channels mediate insulin-dependent activation of AMPK and glucose uptake in cultured rat podocytes. The effects of the TRPC6 inhibitor SKF96365 (A) and of downregulation of TRPC6 channels (B) on the insulin-dependent activation of AMPK. Cell lysates were subjected to immunoblotting analysis using anti-AMPK $\alpha$ and anti-pAMPK $\alpha\left(\mathrm{Thr}^{172}\right)$ antibodies. Values are reported as the means \pm SEMs of four independent experiments. ${ }^{*} \mathrm{P}<0.05$ compared to control. The effects of the TRPC6 inhibitors SKF96365 (C), SAR7334 (D) and of downregulation of TRPC6 channels (E) on insulin-dependent increases in glucose uptake. Uptake measurements were performed after the addition of $1 \mu \mathrm{Ci}$ of $\left[1,2-{ }^{3} \mathrm{H}\right]$-deoxy-D-glucose diluted in non-radioactive glucose to a final concentration of $300 \mathrm{nM}$ insulin. Values are reported as the means \pm SEMs of four to five independent experiments. $* \mathrm{P}<0.05$ compared to control. 


\section{$\begin{array}{ll}\text { Cellular Physiology } & \text { Cell Physiol Biochem 2018;51:393-410 } \\ \text { Dol: 10.1159/000495236 } & \text { (O 2018 The Author(s). Published by S. Karger AG, Basel }\end{array}$ and Biochemistry Poblished online: 17 TNovember 2018 (1) 2018 www.karger.com/cpb

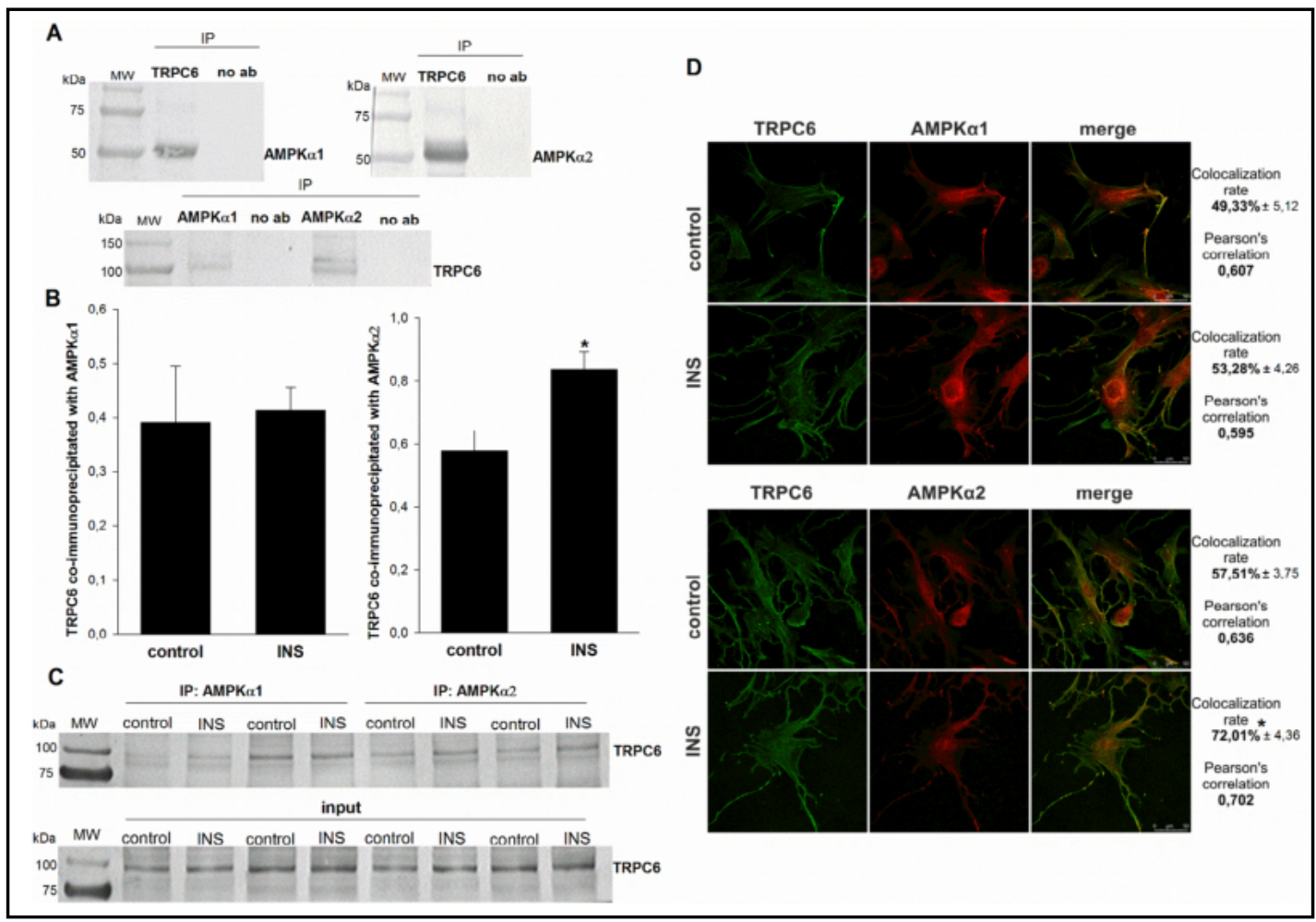

Fig. 4. The role of insulin in TRPC6 channel interactions with AMPK $\alpha$ subunits in cultured rat podocytes. (A) Immunoblots showing that the AMPK $\alpha 1$ and AMPK $\alpha 2$ subunits are associated with immunoprecipitated TRPC6 in podocyte extracts and that, conversely, TRPC6 is associated with immunoprecipitated AMPK 1

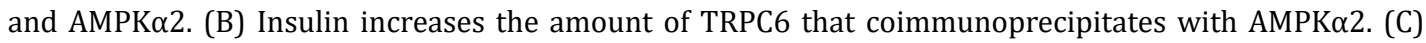
Representative immunoblots. (D) Podocytes were seeded onto coverslips and incubated with or without insulin (300 nM, $5 \mathrm{~min}$ ). The cells were than immunoblotted with anti-TRPC6 and anti-AMPK 1 or antiAMPK $\alpha 2$ antibodies as indicated. Quantitative analysis of protein colocalization was performed with LAS AF 3.3.0 software $\left(n=8-10,{ }^{*} \mathrm{P}<0.05\right)$. The pixel intensities were quantified and the results are reported as Pearson's correlation coefficients and colocalization rates (\%).

investigated the influence of TRPC6 activity on ROCK1 and ROCK2 levels in rat podocytes. ROCK is a major downstream effector of the RhoA kinase [28]. The TRPC6 inhibitor SKF96365 did not influence ROCK kinase levels (Fig. 8A, C). Moreover, downregulation of TRPC6 by siRNA decreased the ROCK1 level by $23 \%$ (from $0.644 \pm 0.036$ to $0.488 \pm 0.014, P<0.05$ ) without affecting ROCK2 expression (Fig. 8B, D). Taken together, these results suggest that downregulation of TRPC6 attenuated the insulin-dependent activation of downstream targets of Rho kinases in podocytes.

TRPC6 channels regulate the insulin-dependent remodeling of the actin cytoskeleton in podocytes

The dynamics of actin filament assembly/disassembly and its organization in cells are regulated by several actin-binding proteins, including ADF/cofilins [29]. In addition, PAK signals to cofilin in response to insulin, thereby facilitating cortical actin remodeling and glucose uptake in skeletal muscle cells [30]. Accordingly, next we examined the effects of insulin on cofilin phosphorylation in podocytes. Notably, cofilin is activated when it is dephosphorylated. We found that insulin stimulation $(300 \mathrm{nM}, 5 \mathrm{~min})$ decreased the p-cofilin level by about $25 \%$ (1.46 \pm 0.11 vs. control $1.95 \pm 0.10, P<0.05$, Fig. 9$)$ in cultured rat podocytes. Preincubation of the cells with SKF96365 (Fig. 9A) or downregulation of TRPC6 by siRNA (Fig. 9B) abolished the effect of insulin on cofilin phosphorylation. 


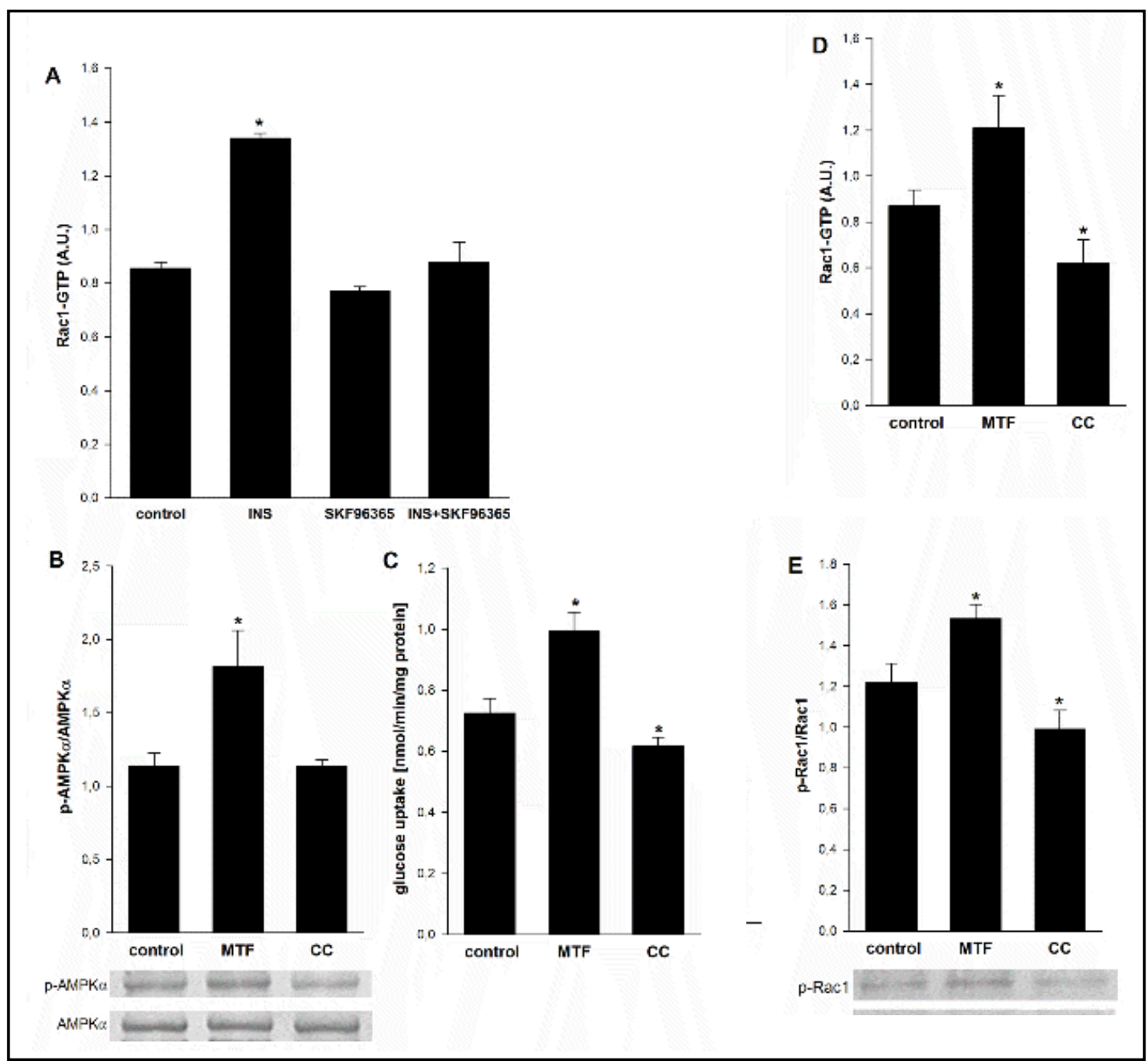

Fig. 5. The influence of TRPC channels and AMPK on Rac1 activity in cultured rat podocytes. (A) Cells were incubated for $5 \mathrm{~min}$ with $300 \mathrm{nM}$ insulin in the presence or absence of the TRPC6 inhibitor SKF96365 (10 $\mu \mathrm{M}, 20 \mathrm{~min})$. Cell lysates $(20 \mu \mathrm{g})$ were subjected to the G-LISA assay, and absorbance was read at $490 \mathrm{~nm}$. The data are background-subtracted. Values are reported as the means \pm SEMs of six independent experiments. $* \mathrm{P}<0.05$ compared to control. The effect of the AMPK activator metformin ( $2 \mathrm{mM})$ and the AMPK inhibitor compound C (100 $\mu \mathrm{M})$ on AMPK activity (B) and on glucose uptake (C). The effect of AMPK on the regulation of Rac1 activity (D) and on serine 71 phosphorylation of Rac1 (E). Values are reported as the means \pm SEMs of four to six independent experiments. ${ }^{*} \mathrm{P}<0.05$ compared to control.

Phosphorylation of cofilin on serine3 leads to reduced actin binding and to actin depolymerization [31]. We found that insulin increased the colocalization of cofilin with actin and that TRPC6 inhibition decreased this effect in podocytes (Fig. 9C). Taken together, these results support accumulating evidence that TRPC6 participates in the regulation of actin dynamics in podocytes and suggest that this function is mediated in part by cofilin. 


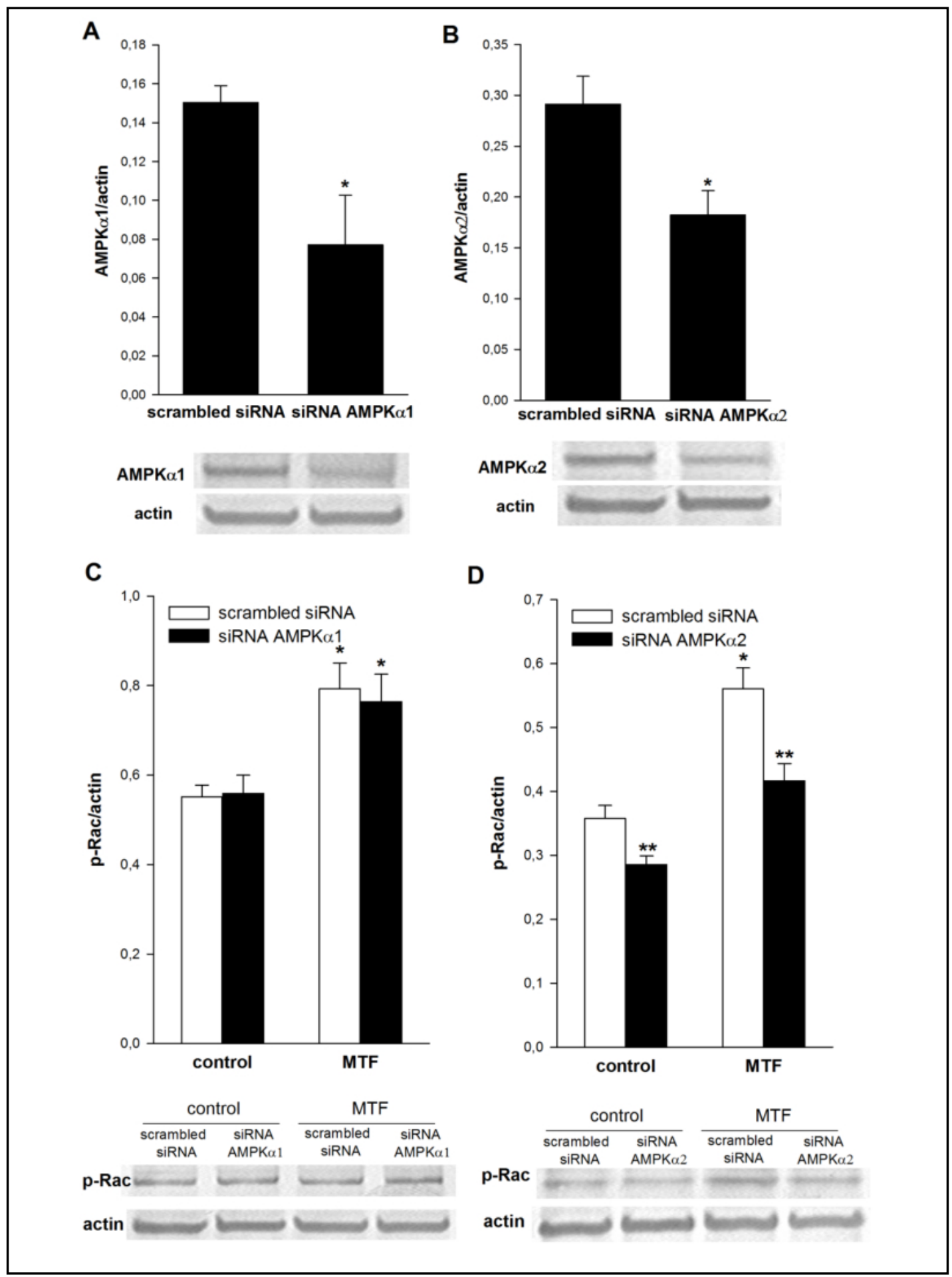

Fig. 6. The role of AMPK $\alpha 1$ and $A M P K \alpha 2$ subunits in the regulation of Rac1 activity. The effects of small interfering RNA targeting transcripts of the AMPK $\alpha 1$ or AMPK $\alpha 2$ subunit in cultured rat podocytes. Densitometry was performed to evaluate the expression of AMPK $\alpha 1$ (A) and AMPK $\alpha 2$ (B), and the band signals were normalized using signals of actin bands. Controls were transfected with scrambled siRNA. The influence of downregulation of AMPK $\alpha 1$ (C) and AMPK $\alpha 2$ (D) on Rac1 phosphorylation. Values are reported as the means \pm SEMs of four independent experiments. ${ }^{*} \mathrm{P}<0.05$ compared to control, ${ }^{* *} \mathrm{P}<0.05$ compared to the appropriate control with scrambled siRNA. 


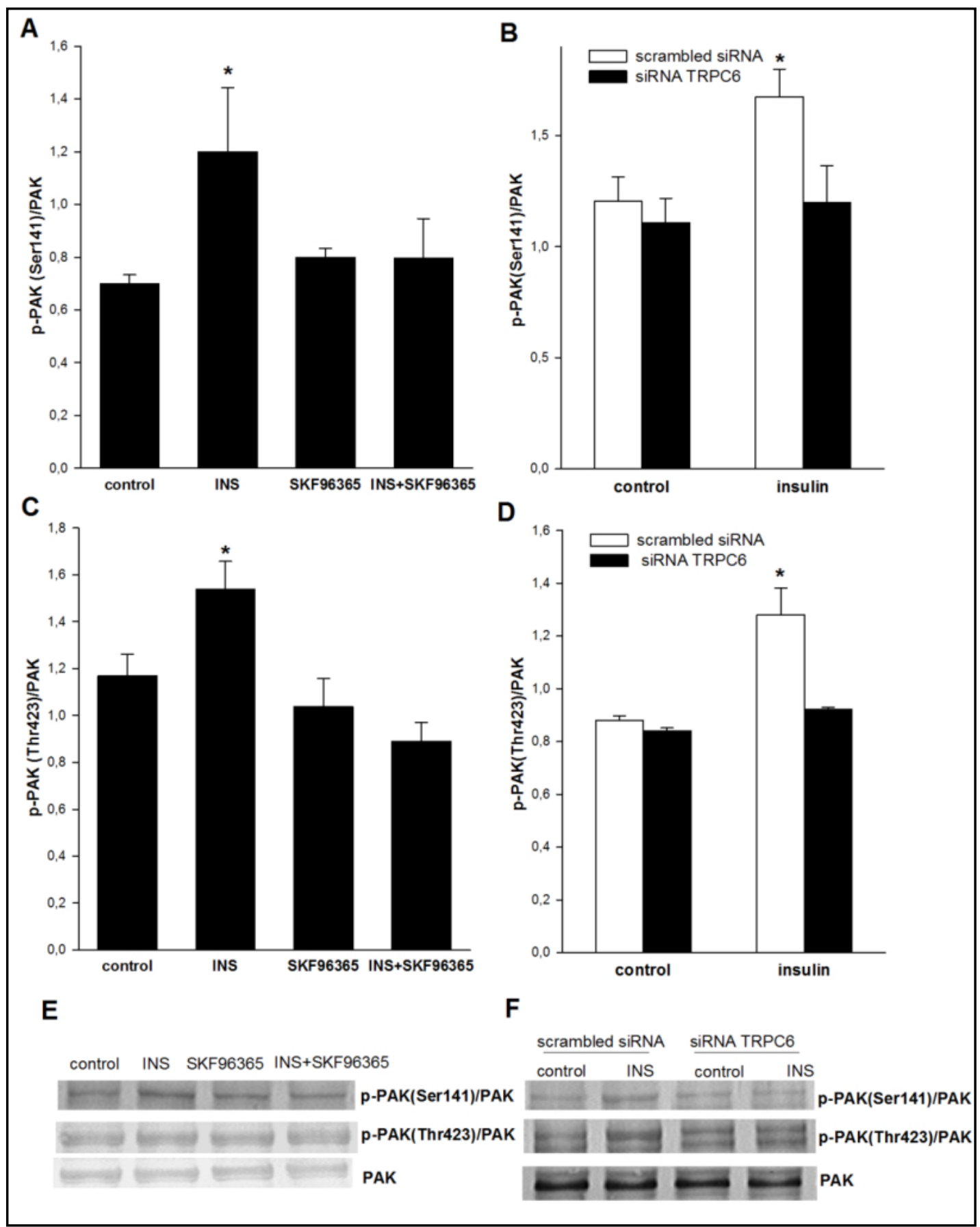

Fig. 7. The role of TRPC channels in insulin-mediated phosphorylation of p21-activated kinase (PAK) in cultured rat podocytes. Podocytes were incubated for 5 min with $300 \mathrm{nM}$ insulin in the presence or absence of the TRPC channel inhibitor SKF96365 (A, C) or TRPC6 siRNA (B, D). Densitometric analysis of the corresponding bands was performed, and values are reported as the ratios of the band intensities for p-PAK (Ser ${ }^{141}$ ) or p-PAK $\left(\mathrm{Thr}^{423}\right.$ ) to PAK. Values are reported as the means \pm SEMs of four to six independent experiments. ${ }^{*} \mathrm{P}<0.05$ compared to control. 


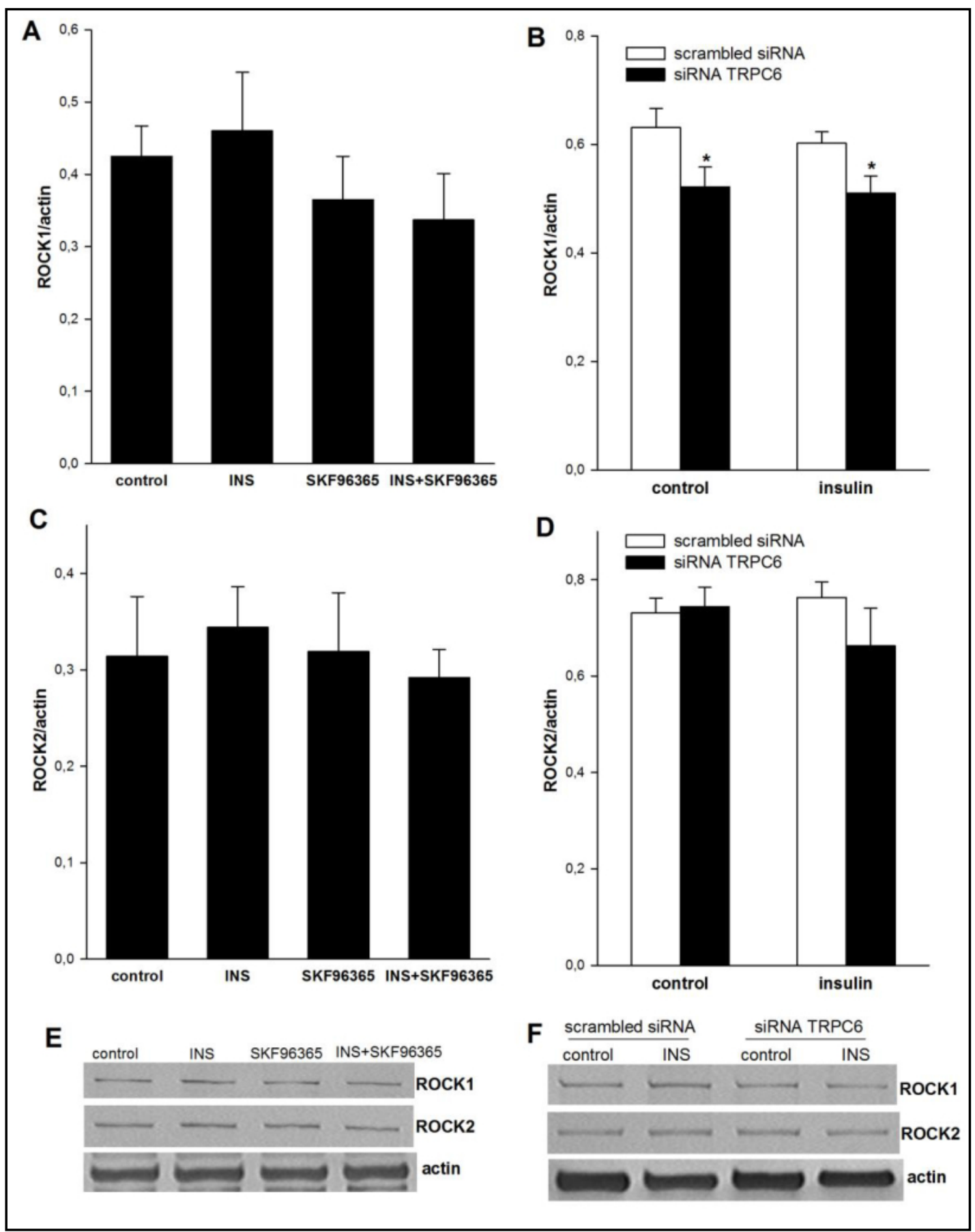

Fig. 8. The influence of TRPC6 channels on ROCK1 and ROCK2 expression in podocytes. Podocytes were incubated for 5 min with $300 \mathrm{nM}$ insulin in the presence or absence of the TRPC channel inhibitor SKF96365 $(A, C)$ or TRPC6 siRNA (B, D). Densitometric analysis of the corresponding bands was performed, and values are reported as the ratios of the band intensities for ROCK1 or ROCK2 to actin. Values are reported as the means \pm SEMs of four to six independent experiments. ${ }^{*} \mathrm{P}<0.05$ compared to control. 


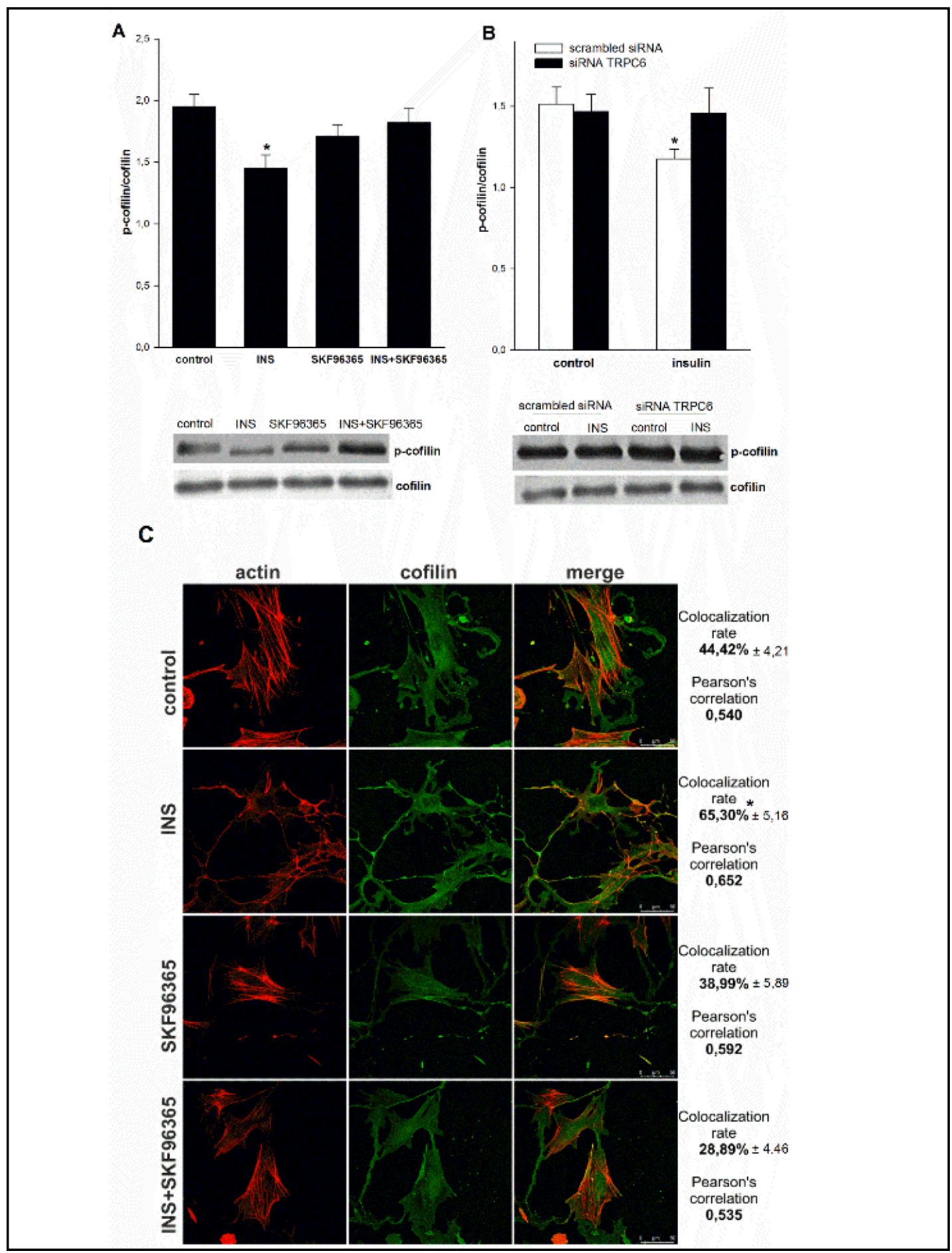

Fig. 9. TRPC6 channel-mediated insulin-dependent activation of cofilin and regulate insulin-induced changes in the colocalization of actin and cofilin in cultured rat podocytes. The effects of the TRPC channel inhibitor SKF96365 (A) or TRPC6 siRNA (B) on the insulin-dependent dephosphorylation of cofilin. Values are reported as the means \pm SEMs of four to six independent experiments. ${ }^{*} \mathrm{P}<0.05$ compared to untreated podocytes. (C) Rat podocytes seeded onto coverslips were incubated for 5 min with $300 \mathrm{nM}$ insulin in the presence or absence of the TRPC channel inhibitor SKF96365. The cells were then immunostained with anticofilin antibody and isothiocyanate phalloidin to detect actin. Quantitative analysis of protein colocalization was performed with LAS AF 3.3.0 software $\left(n=10,{ }^{*} \mathrm{P}<0.05\right)$. The pixel intensities were quantified, and the results are reported as Pearson's correlation coefficients and colocalization rates (\%). 


\section{Discussion}

This study showed that the TRPC6-dependent activation of AMPK $\alpha 2$ signaling pathways is a novel mechanism for the insulin-mediated regulation of actin cytoskeleton dynamics and glucose uptake in podocytes. The proposed mechanism, which is based on our data, is shown in Fig. 10. First, insulinstimulated glucose uptake and actin cytoskeleton reorganization depends on TRPC6 channel activation. Second, activation of the AMPK $\alpha$ signaling pathway is TRPC6-dependent. Third, insulin regulates the interaction of TRPC6 with AMPK $\alpha 2$ in cultured rat podocytes. Fourth, AMPK and TRPC6 activation are required to stimulate Rac1 signaling pathways.

We recently demonstrated that the insulin-mediated regulation of the contractile apparatus and filtration barrier permeability relies on TRPC6-dependent activation of PKGI $\alpha$ signaling pathways. Our studies found that insulin induced the reorganization of actin via TRPC6-dependent $\mathrm{Ca}^{2+}$ entry [11]. The present study confirmed the role of TRPC6 in the regulation of insulin-dependent signaling pathways and actin dynamics. Moreover, we demonstrated for the first time that TRPC6 plays a role in the regulation of AMPK activity and glucose uptake in cultured rat podocytes.

AMPK is a major regulator of insulin-dependent glucose uptake and insulin signaling in podocytes [18]. Phosphorylation of AMPK at Thr172 is required for the activation of AMPK [32], and $\mathrm{Ca}^{2+} /$ calmodulin-dependent CaMKK- $\beta$ activates AMPK in various cell types, including podocytes [33-35]. CaMKK- $\beta$ activity depends on increases in intracellular calcium, and insulin induces calcium flux into cells $[9,11]$. Here we demonstrated that insulin induced a change in AMPK phosphorylation through TRPC6 activation. Our results showed that insulin effect on glucose uptake in podocytes depends on AMPK activity which is regulated by TRPC6. Thus, we conclude that TRPC6 is upstream regulator of AMPK activity in podocytes. We also found, that insulin increased the amount of TRPC6 colocalized with the AMPK $\alpha 2$ subunit in podocytes. Others have also demonstrated a link between TRPC and AMPK activity. For example, TRPC1 knockdown in endothelial cells prevents PAR1 agonist peptide-induced AMPK $\alpha$ phosphorylation [36]. It is possible that AMPK and TRPC3 are part of the same signaling pathway that affects the cytoskeletal network and erythrocyte survival [37]. We assume that AMPK function depends on TRPC6-regulated calcium ion flux and we demonstrated that inhibiting TRPC 6 channels and knocking down TRPC6 expression blocked insulin-dependent glucose uptake. We observed that the basal glucose uptake was not different between SKF96365- or SAR7334-treated and TRPC6 siRNA-treated cells versus control cells; this is consistent with the fact that basal glucose uptake does not involve GLUT4 translocation. 


\section{Cellular Physiology Cell Physiol Biochem 2018;51:393-410 \begin{tabular}{ll|l} 
and Biochemistry & $\begin{array}{l}\text { DOl: 10.1159/000495236 } \\
\text { Published online: 17 November } 2018\end{array}$ & $\begin{array}{l}\text { (2018 The Author(s). Published by S. Karger AG, Basel } \\
\text { www.karger.com/cpb }\end{array}$ \\
\cline { 2 - 3 }
\end{tabular} \\ Rachubik et al.: Insulin Regulates TRPC6-AMPK Pathway in Podocytes}

Recently, it was demonstrated that SAR7334 is particularly useful as it blocks TRPC6 at low nanomolar levels ( IC $_{50} 9.5 \mathrm{nM}$ ), blocks TRPC3 and TRPC7 at orders of magnitude higher concentrations ( IC $_{50} 282$ and $226 \mathrm{nM}$, respectively) [38]. Additionally, Dryer's group showed that SAR7334 is selective inhibitor of TRPC6 in podocytes in low nanomolar concentration [39]. The higher concentration $(1 \mu \mathrm{M})$ cannot entirely exclude a role for TRPC3-dependent entry of $\mathrm{Ca}^{2+}$ into podocytes.

Insulin and muscle contraction are the major known mediators of GLUT4 translocation under physiological conditions [40,41]. The importance of podocyte insulin signaling in the pathogenesis of diabetic kidney disease is suggested by the observation that podocytes isolated from diabetic $\mathrm{db} / \mathrm{db}$ mice cannot phosphorylate Akt in response to insulin and do not translocate GLUT4 to the plasma membrane after insulin stimulation [42]. We suggest that insulin induces the TRPC6-dependent entry of $\mathrm{Ca}^{2+}$ into podocytes, the translocation of GLUT4 to the membrane, and, consequently, an increase in glucose uptake in podocytes. However, this needs further investigation. Others have shown that TRPC3 knockdown reduces insulin-mediated glucose uptake in skeletal muscle cells. Moreover, TRPC3 and GLUT4 colocalize in the t-tubule system, which is responsible for insulin-dependent glucose uptake [43]. It is clear that the ability of podocytes to precisely regulate intracellular $\mathrm{Ca}^{2+}$ levels plays a crucial role in proper glucose uptake.

The rho family GTPases act as molecular switches that are best known for their pivotal roles in the dynamic regulation of the actin cytoskeleton. The mammalian Rho family has at least 20 distinct members, of which RhoA, Rac1, and Cdc42 are the most extensively studied [44]. Rac1 is a major regulator of actin remodeling, and cytoskeletal rearrangement is required for GLUT4 translocation in response to insulin [26].

These findings suggest that Rac1 and downstream signaling to the actin cytoskeleton constitute an important dysfunctional pathway in insulin-resistant states. In podocytes, cells that are sensitive to insulin, this mechanism may not be examined. The results presented here provide evidence that activation of AMPK $\alpha 2$ and TRPC6 are required for insulin-dependent Rac1 signaling pathway stimulation in podocytes. We further demonstrated that the insulinmediated activation of downstream targets of Rho kinases was TRPC6 dependent. Inhibition of TRPC6 activity attenuated the effect of insulin on PAK phosphorylation, decreasing ROCK1 expression and cofilin activation. Insulin-stimulated Rac1 also activates the PAK1 serine/ threonine kinase in skeletal muscle [22]. Moreover, PAK1 inhibition reduces insulin-induced cortical actin remodeling, cofilin activation, and GLUT4 translocation [30]. It is likely that the diminished activity of Rac1 and PAK1 in an insulin-resistant state leads to functional defects in proteins involved in actin remodeling that are necessary for glucose uptake in podocytes. Another group also demonstrated that the ability of insulin to increase glucose transport is attenuated by ROCK1 suppression [45]. This suggests that a decrease in ROCK1 expression in podocytes after downregulation of TRPC6 additionally reduces insulin-dependent glucose transport.

Rac1 is also necessary for the assembly of the membrane-located superoxide-producing NADPH oxidase (NOX) complexes, where it is required for the electron transfer from NADPH to oxygen. NOX isoforms NOX1 and NOX2 are activated via Rac1 having essential roles in physiology and in several human diseases [46]. Recently it was demonstrated that NADPH oxidase is also required to TRPC6 activation in the presence of insulin [11].

Taken together, our data demonstrate that insulin induces the activation of PAK1 and cofilin-1, increases the colocalization of cofilin with actin, and, as a consequence, induces actin remodeling and glucose uptake. Cofilin disassembles actin, thereby maintaining the flexibility of actin remodeling and supporting the regeneration of free monomeric actin for further polymerization. This active cycling of actin as mediated by insulin is necessary for actin dynamics and to facilitate GLUT4 translocation to the surface of muscle cells [23]. 


\section{Cellular Physiology Cell Physiol Biochem 2018;51:393-410 \begin{tabular}{ll|l} 
and BiOChemistry & DOl: 10.1159/000495236 & $\begin{array}{l}\text { (c) } 2018 \text { The Author(s). Published by S. Karger AG, Basel } \\
\text { www.karger.com/cpb }\end{array}$
\end{tabular}

\section{Conclusion}

In summary, our results add to accumulating evidence that TRPC6 participates in the insulin-mediated regulation of actin dynamics in podocytes and suggest that this function is mediated, at least in part, by cofilin. Thus, cofilin dephosphorylation might be attractive as a pharmacological target in order to ensure appropriate actin turnover in diabetes with insulin resistance and to ensure GLUT4 function and glucose uptake.

\section{Acknowledgements}

This work was supported by grants from the National Science Center (grants 2014/14/E/ NZ4/00358 and 2015/17/B/NZ4/02658).

\section{Disclosure Statement}

None of the authors have any competing interests.

\section{References}

1 Rawshani A, Gudbjornsdottir S: Mortality and Cardiovascular Disease in Type 1 and Type 2 Diabetes; N Engl J Med 2017;377:300-301.

-2 Ritz E, Rychlik I, Locatelli F, Halimi S: End-stage renal failure in type 2 diabetes: A medical catastrophe of worldwide dimensions. Am J Kidney Dis 1999;34:795-808.

-3 Coward RJ, Welsh GI, Yang J, Tasman C, Lennon R, Koziell A, Satchell S, Holman GD, Kerjaschki D, Tavare JM, Mathieson PW, Saleem MA: The human glomerular podocyte is a novel target for insulin action. Diabetes 2005;54:3095-3102.

4 Rogacka D, Piwkowska A, Audzeyenka I, Angielski S, Jankowski M: SIRT1-AMPK crosstalk is involved in high glucose-dependent impairment of insulin responsiveness in primary rat podocytes. Exp Cell Res 2016;349:328-338.

5 Welsh GI, Hale LJ, Eremina V, Jeansson M, Maezawa Y, Lennon R, Pons DA, Owen RJ, Satchell SC, Miles MJ, Caunt CJ, McArdle CA, Pavenstadt H, Tavare JM, Herzenberg AM, Kahn CR, Mathieson PW, Quaggin SE, Saleem MA, Coward RJ: Insulin signaling to the glomerular podocyte is critical for normal kidney function. Cell Metab 2010;12:329-340.

-6 Piwkowska A, Rogacka D, Kasztan M, Angielski S, Jankowski M: Insulin increases glomerular filtration barrier permeability through dimerization of protein kinase G type Ialpha subunits. Biochim Biophys Acta 2013;1832:791-804.

7 Piwkowska A, Rogacka D, Audzeyenka I, Kasztan M, Angielski S, Jankowski M: Insulin increases glomerular filtration barrier permeability through PKGIalpha-dependent mobilization of BKCa channels in cultured rat podocytes. Biochim Biophys Acta 2015;1852:1599-1609.

8 Kim EY, Dryer SE: Effects of insulin and high glucose on mobilization of slo1 BKCa channels in podocytes. J Cell Physiol 2011;226:2307-2315.

-9 Kim EY, Anderson M, Dryer SE: Insulin increases surface expression of TRPC6 channels in podocytes: role of NADPH oxidases and reactive oxygen species. Am J Physiol Renal Physiol 2012;302:F298-307.

10 Piwkowska A, Rogacka D, Audzeyenka I, Kasztan M, Angielski S, Jankowski M: Intracellular calcium signaling regulates glomerular filtration barrier permeability: the role of the PKGI $\alpha$-dependent pathway. FEBS Lett 2016;590:1739-1748.

11 Rogacka D, Audzeyenka I, Rachubik P, Rychlowski M, Kasztan M, Jankowski M, Angielski S, Piwkowska A: Insulin increases filtration barrier permeability via TRPC6-dependent activation of PKGIalpha signaling pathways. Biochim Biophys Acta 2017;1863:1312-1325. 


\section{Cellular Physiology Cell Physiol Biochem 2018;51:393-410

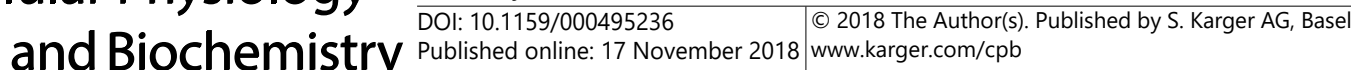

12 Krall P, Canales CP, Kairath P, Carmona-Mora P, Molina J, Carpio JD, Ruiz P, Mezzano SA, Li J, Wei C, Reiser J, Young JI, Walz K: Podocyte-specific overexpression of wild type or mutant trpc6 in mice is sufficient to cause glomerular disease. PLoS One 2010;5:e12859.

13 Jiang L, Ding J, Tsai H, Li L, Feng Q Miao J, Fan Q: Over-expressing transient receptor potential cation channel 6 in podocytes induces cytoskeleton rearrangement through increases of intracellular Ca2+ and RhoA activation. Exp Biol Med (Maywood) 2011;236:184-193.

14 Dryer SE, Reiser J: TRPC6 channels and their binding partners in podocytes: role in glomerular filtration and pathophysiology. Am J Physiol Renal Physiol 2010;299:F689-701.

15 Mathieson PW: The podocyte as a target for therapies--new and old. Nat Rev Nephrol 2011;8:52-56.

-16 Fisher JS, Gao J, Han DH, Holloszy JO, Nolte LA: Activation of AMP kinase enhances sensitivity of muscle glucose transport to insulin. Am J Physiol Endocrinol Metab 2002;282:E18-23.

$\checkmark 17$ Jing M, Cheruvu VK, Ismail-Beigi F: Stimulation of glucose transport in response to activation of distinct AMPK signaling pathways. Am J Physiol Cell Physiol 2008;295:C1071-1082.

18 Rogacka D, Piwkowska A, Audzeyenka I, Angielski S, Jankowski M: Involvement of the AMPK-PTEN pathway in insulin resistance induced by high glucose in cultured rat podocytes. Int J Biochem Cell Biol 2014;51:120-130.

19 Zeqiraj E, Filippi BM, Deak M, Alessi DR, van Aalten DM: Structure of the LKB1-STRAD-MO25 complex reveals an allosteric mechanism of kinase activation. Science 2009;326:1707-1711.

-20 Sylow L, Moller LLV, Kleinert M, D’Hulst G, De Groote E, Schjerling P, Steinberg GR, Jensen TE, Richter EA: Rac1 and AMPK Account for the Majority of Muscle Glucose Uptake Stimulated by Ex Vivo Contraction but Not In vivo Exercise. Diabetes 2017;66:1548-1559.

21 Sylow L, Moller LL, Kleinert M, Richter EA, Jensen TE: Stretch-stimulated glucose transport in skeletal muscle is regulated by Rac1. J Physiol 2015;593:645-656.

-22 Sylow L, Jensen TE, Kleinert M, Hojlund K, Kiens B, Wojtaszewski J, Prats C, Schjerling P, Richter EA: Rac1 signaling is required for insulin-stimulated glucose uptake and is dysregulated in insulin-resistant murine and human skeletal muscle. Diabetes 2013;62:1865-1875.

23 Chiu TT, Patel N, Shaw AE, Bamburg JR, Klip A: Arp2/3- and cofilin-coordinated actin dynamics is required for insulin-mediated GLUT4 translocation to the surface of muscle cells. Mol Biol Cell 2010;21:3529-3539.

-24 Tsakiridis T, Taha C, Grinstein S, Klip A: Insulin activates a p21-activated kinase in muscle cells via phosphatidylinositol 3-kinase. J Biol Chem 1996;271:19664-19667.

25 Piwkowska A, Rogacka D, Jankowski M, Kocbuch K, Angielski S: Hydrogen peroxide induces dimerization of protein kinase $\mathrm{G}$ type Ialpha subunits and increases albumin permeability in cultured rat podocytes. J Cell Physiol 2012;227:1004-1016.

-26 JeBailey L, Wanono O, Niu W, Roessler J, Rudich A, Klip A: Ceramide- and oxidant-induced insulin resistance involve loss of insulin-dependent Rac-activation and actin remodeling in muscle cells. Diabetes 2007;56:394-403.

27 Lei M, Lu W, Meng W, Parrini MC, Eck MJ, Mayer BJ, Harrison SC: Structure of PAK1 in an autoinhibited conformation reveals a multistage activation switch. Cell 2000;102:387-397.

28 Burridge K, Wennerberg K: Rho and Rac take center stage. Cell 2004;116:167-179. Bamburg JR, Wiggan OP: ADF/cofilin and actin dynamics in disease. Trends Cell Biol 2002;12:598-605.

-30 Tunduguru R, Chiu TT, Ramalingam L, Elmendorf JS, Klip A, Thurmond DC: Signaling of the p21-activated kinase (PAK1) coordinates insulin-stimulated actin remodeling and glucose uptake in skeletal muscle cells. Biochem Pharmacol 2014;92:380-388.

-31 Moriyama K, Iida K, Yahara I: Phosphorylation of Ser-3 of cofilin regulates its essential function on actin. Genes Cells 1996;1:73-86.

-32 Hawley SA, Selbert MA, Goldstein EG, Edelman AM, Carling D, Hardie DG: 5'-AMP activates the AMPactivated protein kinase cascade, and $\mathrm{Ca} 2+$ /calmodulin activates the calmodulin-dependent protein kinase I cascade, via three independent mechanisms. J Biol Chem 1995;270:27186-27191.

-33 Piwkowska A, Rogacka D, Jankowski M, Angielski S: Extracellular ATP through P2 receptors activates AMPactivated protein kinase and suppresses superoxide generation in cultured mouse podocytes. Exp Cell Res 2011;317:1904-1913.

34 Chen X, Zhao X, Lan F, Zhou T, Cai H, Sun H, Kong W: Hydrogen Sulphide Treatment Increases Insulin Sensitivity and Improves Oxidant Metabolism through the CaMKKbeta-AMPK Pathway in PA-Induced IR C2C12 Cells. Sci Rep 2017;7:13248. 


\section{Cellular Physiology Cell Physiol Biochem 2018;51:393-410

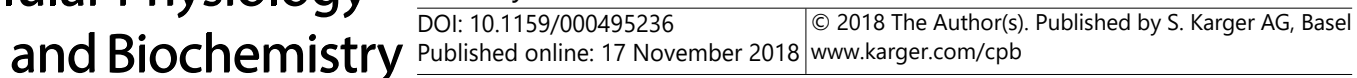 \\ Rachubik et al.: Insulin Regulates TRPC6-AMPK Pathway in Podocytes}

-35 Nakanishi A, Hatano N, Fujiwara Y, Sha'ri A, Takabatake S, Akano H, Kanayama N, Magari M, Nozaki N, Tokumitsu H: AMP-activated protein kinase-mediated feedback phosphorylation controls the $\mathrm{Ca}(2+) /$ calmodulin (CaM) dependence of $\mathrm{Ca}(2+) / \mathrm{CaM}$-dependent protein kinase kinase beta. J Biol Chem 2017;292:19804-19813.

-36 Bair AM, Thippegowda PB, Freichel M, Cheng N, Ye RD, Vogel SM, Yu Y, Flockerzi V, Malik AB, Tiruppathi C: $\mathrm{Ca} 2+$ entry via TRPC channels is necessary for thrombin-induced NF-kappaB activation in endothelial cells through AMP-activated protein kinase and protein kinase Cdelta. J Biol Chem 2009;284:563-574.

-37 Hirschler-Laszkiewicz I, Tong Q, Waybill K, Conrad K, Keefer K, Zhang W, Chen SJ, Cheung JY, Miller BA: The transient receptor potential (TRP) channel TRPC3 TRP domain and AMP-activated protein kinase binding site are required for TRPC3 activation by erythropoietin. J Biol Chem 2011;286:30636-30646.

-38 Maier T, Follmann M, Hessler G, Kleemann HW, Hachtel S, Fuchs B, Weissmann N, Linz W, Schmidt T, Lohn M, Schroeter K, Wang L, Rutten H, Strubing C: Discovery and pharmacological characterization of a novel potent inhibitor of diacylglycerol-sensitive TRPC cation channels. Br J Pharmacol 2015;172:3650-3660.

39 Kim EY, Roshanravan H, Dryer SE: Changes in podocyte TRPC channels evoked by plasma and sera from patients with recurrent FSGS and by putative glomerular permeability factors. Biochim Biophys Acta 2017;1863:2342-2354.

40 Mueckler M: Facilitative glucose transporters. Eur J Biochem 1994;219:713-725.

41 Coward R, Fornoni A: Insulin signaling: implications for podocyte biology in diabetic kidney disease. Curr Opin Nephrol Hypertens 2015;24:104-110.

\$2 Guzman J, Jauregui AN, Merscher-Gomez S, Maiguel D, Muresan C, Mitrofanova A, Diez-Sampedro A, Szust J, Yoo TH, Villarreal R, Pedigo C, Molano RD, Johnson K, Kahn B, Hartleben B, Huber TB, Saha J, Burke GW, 3rd, Abel ED, Brosius FC, Fornoni A: Podocyte-specific GLUT4-deficient mice have fewer and larger podocytes and are protected from diabetic nephropathy. Diabetes 2014;63:701-714.

43 Lanner JT, Bruton JD, Assefaw-Redda Y, Andronache Z, Zhang SJ, Severa D, Zhang ZB, Melzer W, Zhang SL, Katz A, Westerblad H: Knockdown of TRPC3 with siRNA coupled to carbon nanotubes results in decreased insulin-mediated glucose uptake in adult skeletal muscle cells. Faseb j 2009;23:1728-1738.

44 Etienne-Manneville S, Hall A: Rho GTPases in cell biology. Nature 2002;420:629-635.

45 Chun KH, Araki K, Jee Y, Lee DH, Oh BC, Huang H, Park KS, Lee SW, Zabolotny JM, Kim YB: Regulation of glucose transport by ROCK1 differs from that of ROCK2 and is controlled by actin polymerization. Endocrinology 2012;153:1649-1662.

46 Acevedo A, Gonzalez-Billault C: Crosstalk between Rac1-mediated actin regulation and ROS production. Free Radic Biol Med 2018;116:101-113. 